\title{
PENGEMBANGAN MEDIA PEMBELAJARAN UNTUK MATA KULIAH BAHASA INDONESIA BERBASIS ANDROID
}

\author{
Agus Milu Susetyo \\ Program Studi Pendidikan Bahasa dan Sastra Indonesia, \\ Fakultas Keguruan dan Ilmu Pendidikan, Universitas Muhammadiyah Jember, \\ Jalan Karimata No. 49 Jember 68121 Jawa Timur Indonesia \\ agusmilus@unmuhjember.ac.id
}

\begin{abstract}
ABSTRAK
Penelitian ini di awali dari fenomena adanya smartphone Android di kalangan mahasiswa Universitas Muhammadiyah Jember. Berdasarkan latar belakang ini peneliti mengembangkan media pembelajaran pada mata kuliah bahasa Indonesia yang diterapkan ke dalam smartphone milik mahasiswa. Tujuan penelitian untuk mengembangkan media pembelajaran yang inovatif khususnya untuk mata kuliah bahasa Indonesia. Dengan metode pengembangan dan uji coba kepada mahasiswa, ahli materi dan ahli media mendapatkan hasil bahwa produk yang dikembangkan peneliti layak digunakan untuk mata kuliah Bahasa Indonesia. meskipun demikian ada kelemahan produk ini. (a) aplikasi Android ini belum tersedia di Google Playstore sehingga dosenlah yang mendistribusikan kepada mahasiwa. (b) Cara pengerjaan tugas atau latihan masih terpisah dari produk. (c) pengguna harus menggunakan aplikasi pendukung lainnya berupa Adobe Air.
\end{abstract}

Kata kunci: Pengembangan, Bahasa, Media, Android, Pembelajaran

\section{PENDAHULUAN}

$\mathrm{P}$ erkuliahan atau pembelajaran membutuhkan media (perantara). Menurut Djamarah (2002: 137) media merupakan segala alat bantu apa bisa dijadikan untuk menyalurkan pesan sehingga dapat mampu menggapai tujuan pengajaran. Artinya media tidak terlepas dari proses pembelajaran termasuk juga dengan perkuliahan. Dosen maupun guru selalu menggunakan peran-tara (media) untuk menyampaikan tujuan pembelajaran atau informasi materi pelajaran kepada peserta didinya. Hasil penelitian telah membuktikan bahwa ada berbedaan signifikan hasil pembelajaran antara memakai media dan tidak menggunakan media.

Seiring perkembangan pengatahuan dan teknologi, media pembelajaran pada era sekarang ini jauh lebih berkembang dari-pada media pada jaman dahulu. Tahun 90-an guru dan siswa masih sering dijumpai menggunakan media cetak (buku, LKS, lembaran lepas dll), media audio (radio, rekaman) sebagai media pembelajaran yang sudah mampu memenuhi kebutuhan kegia-tan belajar. Namun terbalik di jaman seka-rang yang serba canggih. Media pembela-jaran semakin berkembang ke arah digital. 
Agus Milu Susetyo: Pengembangan Media Pembelajaran untuk Mata Kuliah Bahasa Indonesia Berbasis Android

Website : https://jurnal.umj.ac.id/index.php/penaliterasiEmail : penaliterasi@umj.ac.id

Kemajuan teknologi memungkinkan smartphone milik mahasiswa tidak hanya digunakan untuk komunikasi dan hiburan melainkan bisa digunakan untuk belajar. Smartphone dengan sistem operasi Android milik mahasiswa Universitas Muhammadiyah Jember masih digunakan hanya untuk bersosial media, komunikasi, hiburan. Celah inilah yang menjadi dasar peneliti berusaha mengembangkan produk media pembelajaran dengan basis smartphone Android. Peneliti menggunakan aplikasi Adobe Flash CS6 untuk mengembangkan media pembelajaran (perkuliahan) pada mata kuliah Bahasa Indonesia. Ketika produk dihasilkan (masih dalam basis flash) dari aplikasi Adobe Flash CS6, peneliti mengubahnya menjadi aplikasi yang bisa di pasang di smartphone Android.

Menurut Ichwan (2016:1) Adobe Flash CS6 merupakan piranti lunak ini dirancang oleh macromedia, tetapi sekarang dikembangkan dan didistribusikan oleh Adobe System. Aplikasi ini banyak dipakai untuk membuat animasi, hiburan, dan berbagai komponen web, dapat disatukan dengan video pada halaman web sehingga mampu memperkaya aplikasi multimedia tersebut. Salah satu peningkatan dari Adobe Flash CS6 adalah bisa mendukung aplikasi Android dan Ios.

Kemajuan teknologi dan pembelajaran harus disinergikan untuk meningkat-kan kualitas pembelajaran (perkuliahan). Guru, dosen atau pendidik harus sadar dengan keadaan ini. Berdasarkan kenyataan inilah peneliti ini melakukan penelitian dan pengembangan media pembelajaran berba-sis Flash untuk OS Android di Mata Kuliah Bahasa Indonesia.

Pendahuluan memuat latar belakang atas suatu masalah serta urgensi dan rasionalisasi dari suatu penelitian yang disajikan secara ringkas, padat, dan jelas; tujuan penelitian; serta teori-teori pendukung, serta hipotesis penelitian jika ada. Penulisan bahasa asing diketik miring (italic). Gunakan drop cap dalam penulisan awal pada bagian pendahuluan.

\section{METODE PENELITIAN}

Tenis penelitian yang digunakan adalah metode pengembangan. Sukmadinata, (2013:164) bahwa penelitian pengemba-ngan adalah salah satu metode penelitian yang berisi langkah-langkah untuk mengembangkan suatu produk baik baru atau memperbaiki produk yang sudah ada sehingga dapat dipertanggungjawabkan. Maksudnya dalam penelitian ini adalah mengadakan penelitian dengan cara mengembangkan media pembelajaran berbasis flash untuk OS Android di Mata Kuliah Bahasa Indonesia.

\section{A. Model Penelitian}

Sementera itu model pengembangan yang digunakan dalam penelitian ini diadaptasi dari model penelitian ADDIE. Model ini merupakan singkatan dari "Analysis, Design, Development or Production, Implementation or Delivery and Evaluations".

B. Sampel dan Populasi Penelitian

Sampel dalam penelitian ini adalah sejumlah 58 mahasiswa semester 1 di lingkungan Universitas Muhammdiyah Jember. Sampel ini dimabil dari populasi secara keseluruhan mahasiswa semester 1 yang menempuh mata kuliah bahasa Indoensia. Sampel tersebut dijadikan peneliti untuk subjek uji coba media yang dikembangkan serta mengisi angket untuk menanyakan respons atas ujicoba media.

C. Instrumen Penelitian

Instrumen yang digunakan dalam penelitian ini adalah angket. Jenis kuesioner yang dipilih adalah tipe tertutup (check list) 
Agus Milu Susetyo: Pengembangan Media Pembelajaran untuk Mata Kuliah Bahasa Indonesia Berbasis Android

Website : https://jurnal.umj.ac.id/index.php/penaliterasiEmail : penaliterasi@umj.ac.id

maksudnya daftar isian yang bersifat tertutup, responden tinggal membubuhkan tanda check pada kolom jawaban yang tersedia. Instrumen angket pada penelitian ini dilaukan untuk memperoleh data dari ahli media, ahli materi, praktisi, dan siswa. Cara tersebut digunakan menjadi panduan mengevaluasi produk yang dikembangkan.

Berikut ini dijabarkan beberapa aspek yang terdapat di angket atau kue-sioner yang diberikan kepada beberapa kelompok responden.

a. Angket untuk ahli media

Angket yang digunakan dalam bentuk tabel dan diberikan kepada dosen TI di Universitas Muhammadiyah Jember. Beberapa aspek yang diisikan dalam angket adalah pemilihan jenis huruf, Pemilihan ukuran huruf, warna huruf, pemilihan background, tampilan gambar, animasi, musil latar, sound, penggunaan bahasa, navigasi, konsistensi tombol, kejelasan petunjuk penggunaan, kemudahan penggu-naan, efisiensi teks, kecepatan slide, kualitas umpan balik

b. Angket untuk ahli materi

Angket yang digunakan dalam bentuk tabel dan diberikan kepada dosen dosen pembina mata kuliah bahasa Indonesia di UM Jember di Universitas Muhammadiyah Jember. Beberapa aspek yang diisikan dalam angket adalah kesesuaian materi dengan tujuan mata kuliah, kejelasan dan sistematika penyam-paian materi, kemenarikan materi, kese-suaian tingkat kesulitan, kejelasan contoh, kejelasan petunjuk pengerjaan, variasi dan tingkat kesulitan soal, ketepatan penggu-naan istilah, kemampuan untuk mendorong rasa ingin tahu, kemandirian, pengetahuan, memotivasi peserta didik.

c. Angket untuk mahasiswa

Angket yang digunakan dalam bentuk tabel dan diberikan kepada maha-siswa.
Mahasiswa yang dimaksud adalah mahasiswa yang sedang menempuh mata kuliah bahasa Indonesia. Dimana media yang dikembangkan untuk memenuhi kebu-tuhan media perkuliahan bagi mereka. Beberapa aspek yang diisikan dalam angket adalah kejelasan petunjuk penggunaan program, kesesuaian dengan kebutu-han peserta didik, mendorong rasa ingin tahu peserta didik, keterbacaan teks/tulisan, manfaat untuk menambah wawasan pengetahuan, terdapat latihan atau tugas sesuai materi pembelajaran, kesesuaian dengan kaidah bahasa indonesia, penggunaan baha-sa secara efektif dan efisien, keragaman penggunaan jenis dan ukuran huruf, tata letak menarik, kualitas ilustrasi, gambar, grafis dan foto, animasi, komposisi warna, daya dukung suara, kejelasan isi materi, variasi soal (tingkat kesulitan), mendukung peserta didik untuk mandiri.

D. Prosedur Penelitian

a) Tahap analisis, tahap ini bertujuan untuk melihat kenyataan yang terjadi dilapangan yaitu pada media apa sajakah yang digunakan pada saat mata kuliah Bahasa Indonesia.

b) Tahap desain, tahap ini meliputi: desain media (produk), penetapan materi (didasarkan pada deskripsi mata kuliah Bahasa Indonesia), layout, secara garis besar media ini berisi materi, dan soal latihan serta contoh-contoh sesuai dengan materi yang sedang dipelajari, dan pengumpulan bahan untuk pembuatan media.

c) Tahap pengembangan, pada tahap ini diawali dengan pembuatan media dengan Adobe Flash CS6. Selanjutnya penelitian melakukan validasi kepada ahli materi, media dan praktisi untuk memperoleh saran, komentar, dan masukan yang dapat digunakan untuk melakukan 
Agus Milu Susetyo: Pengembangan Media Pembelajaran untuk Mata Kuliah Bahasa Indonesia Berbasis Android

Website : https://jurnal.umj.ac.id/index.php/penaliterasiEmail : penaliterasi@umj.ac.id

analisis dan revisi terhadap produk yang dikembangkan.

d) Tahap implementasi, tahap ini merupakan tahap akhir dari prosedur peneilitian pengembangan yang dilakukan peneliti. Tahap akhir ini dilakukan dengan mengujicobakan kepada beberapa mahasiswa tingkat 1 di Univesitas Muhammadiyah Jember. Mereka bertugas mengisi angket untuk mengetahui kelayakan mengenai produk yang dikembangkan. Selain itu juga diujicobakan kepada dosen pengampu mata kuliah Bahasa Indonesia.

E. Teknis Analisis

Analisis data dilakukan dengan cara mendeskripsikan angket yang telah dibagikan kepada ahli dan mahasisa. Berikut pemaparannya.

a. Analisis Data dalam Proses Pengembangan Produk

Data proses pengembangan produk merupakan data deskriptif yang diperoleh dari ahli materi, ahli media, dan praktisi. Komentar, saran, dan masukkan tersebut digunakan sebagai acuan revisi produk. Adapun cara untuk menentukan validasi isi pedoman wawancara adalah sebagai berikut.

$$
\text { CVR }=\frac{\left(n_{B}-\frac{N}{2}\right)}{N}
$$

Keterangan :

CVR : Content Validity Ratio

$\mathrm{N}$ : Jumlah Jawaban Setuju

$\mathrm{N}$ : Total Total

Sumber: Lawshe (dalam Hendriyadi, 2014:4)

b. Analisis Data dalam Penilaian Kelayakyakan Produk

Proses analisis kelayakan produk yang dikembangkan peneliti. Pemerolehan data dari responden selanjutnya dianalisis dengan langkah cara (1) Mengubah data penilaian kualitatif menjadi kuantitatif dengan ketentuan penilaian dalam setiap item angket.
(2) Menghitung data angket dari responden dengan rumus berikut ini.

$$
P=\frac{x}{x i} \times 100 \%
$$

Keterangan:

$P$ : Persentase

$X$ : Jawaban responden dalam satu item

$X i$ : Nilai ideal dalam satu item

$100 \%$ : Konstanta

Sumber: Nugroho, (2014: 56)

c. Kesimpulan

Menentukan kesimpulan data yang sudah dirumuskan. Untuk menentukan kesimpulan, ditetapkan kriteria keberhasi-lan dengan pedoman interpretasi hasil berikut ini. Tabel 1. Indeks Penilaian Angket

\begin{tabular}{|cccc|}
\hline \multicolumn{2}{c}{ Hasil Uji } & Keputusan \\
\cline { 1 - 3 } Kari & Persentase & $\begin{array}{c}\text { Kualif } \\
\text { ikasi }\end{array}$ & \\
\hline 4 & $80 \%-100 \%$ & $\begin{array}{c}\text { Sangat } \\
\text { layak }\end{array}$ & Implementasi \\
\hline 3 & $60 \%-79 \%$ & layak & Implementasi \\
\hline 2 & $50 \%-59 \%$ & $\begin{array}{c}\text { Cukup } \\
\text { layak }\end{array}$ & Revisi \\
\hline 1 & $<50 \%$ & $\begin{array}{c}\text { Kurang } \\
\text { layak }\end{array}$ & Revisi \\
\hline
\end{tabular}

\section{HASIL DAN PEMBAHASAN}

$\mathrm{H}$ asil ujicoba penelitian ini menghasilkan beberapa data. Berikut ini pemaparannya.

A. Hasil Uji Coba Mahasiswa

Berdasarkan angket yang telah disebarkan kepada mahasiswa yang berisi 17 aspek tentang kemampuan media untuk mendukung mata kuliah Bahasa Indonesia. Berdasarkan angket yang digunakan yang dikembangkan mendapatkan hasil "implementatif". Artinya adalah produk yang dikembangkan peneliti dapat diimplementasikan dalam pembelajaran (perkuliahan). Secara rinci berdasarkan angket yang disebarkan kepada sampel mendapatkan hasil seperti di seperti diagram di bawah. 
Agus Milu Susetyo: Pengembangan Media Pembelajaran untuk Mata Kuliah Bahasa Indonesia Berbasis Android

Website : https://jurnal.umj.ac.id/index.php/penaliterasiEmail : penaliterasi@umj.ac.id

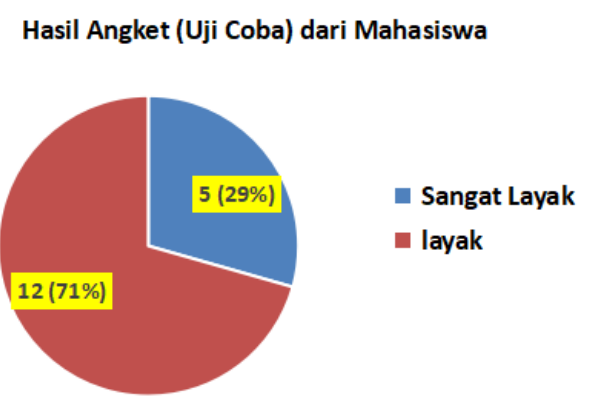

Gambar 1. Diagram lingkaran hasil uji coba kepada mahasiswa

\section{B. Hasil Uji Coba Ahli Media}

Berdasarkan angket yang telah disebarkan kepada ahli media (Triawan Adi C, M.T, dosen TI Universitas Muhammadiyah Jember) 16 aspek yang harus dinilai oleh responden. Aspek tersebut berkaitan erat dengan media yang dikembangkan dari sisi tampilan produk. Hasilnya dari media yang dikembangkan mendapatkan hasil “implementatif'. Artinya adalah produk yang dikembangkan peneliti dapat diimplementasikan dalam pembelajaran (perkuliahan). Secara rinci berdasarkan angket yang disebarkan kepada sampel menda-patkan hasil seperti di seperti diagram berikut.

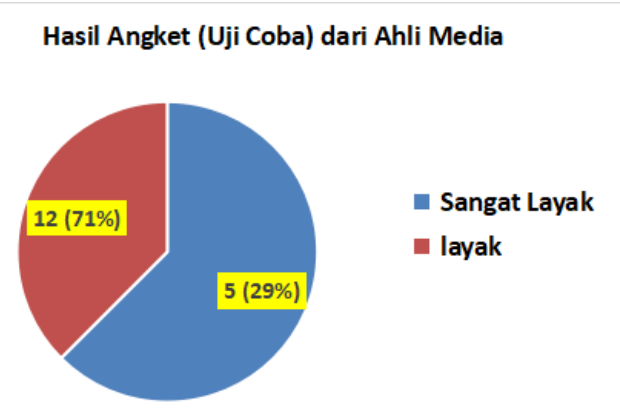

Gambar 2. Diagram lingkaran hasil uji coba kepada ahli media.

\section{Hasil Uji Coba Ahli Materi}

Berdasarkan angket yang telah disebarkan kepada ahli media (Dzarna, M.Pd dan Rofiatul Hima, M.Pd selaku pembimbing mata kuliah Bahasa Indonesia yang berasal dari FKIP UM Jember). 17 aspek yang harus dinilai oleh responden. Aspek tersebut berkaitan erat dengan isi atau konten dari media yang dikembangkan. Hasilnya dari media yang dikembangkan mendapatkan hasil 'implementatif'. media yang dikembangkan dari semua aspek adalah implementatif sehingga dapat digunakan untuk media pembelajaran kepada mahasiswa yang menempuh mata kuliah bahasa Indonesia. Secara rinci berdasarkan angket yang disebarkan kepada sampel mendapatkan hasil seperti di seperti diagram berikut.

Hasil Angket (Uji Coba) dari Ahli Materi

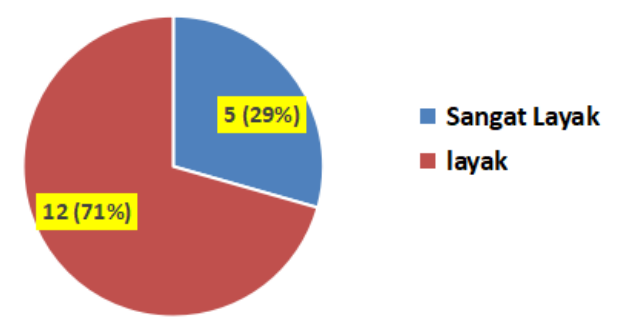

Gambar 3. Diagram lingkaran hasil uji coba kepada ahli materi.

D. Pembahasan

Adapun perangkat lunak komputer yang dapat membuat animasi flash adalah adobe flash dengan berrnama macromedia flash. Program ini dikembangkan perusahaan Macromedia, tetapi sekarang dikembangkan dan didistribusikan oleh Adobe System. Seiring perkembangan jaman, peneliti menggunakan Adobe Flash yang terbaru yaitu Adobe Flash CS6. Alasan utama peneliti menggunakan perangkat lunak versi terbaru karena dapat mendukung untuk pengembangan aplikasi Android dan Ios. Berkat vitur ini dulunya produk flash yang hanya bisa diputar melalui komputer sekarang bisa dimasukkan ke dalam smartphone (gawai) yang berbasis Android atau Ios. Beriku ini tampilan perangkat lunak yang dimaksud. 
Agus Milu Susetyo: Pengembangan Media Pembelajaran untuk Mata Kuliah Bahasa Indonesia Berbasis Android

Website : https://jurnal.umj.ac.id/index.php/penaliterasiEmail : penaliterasi@umj.ac.id

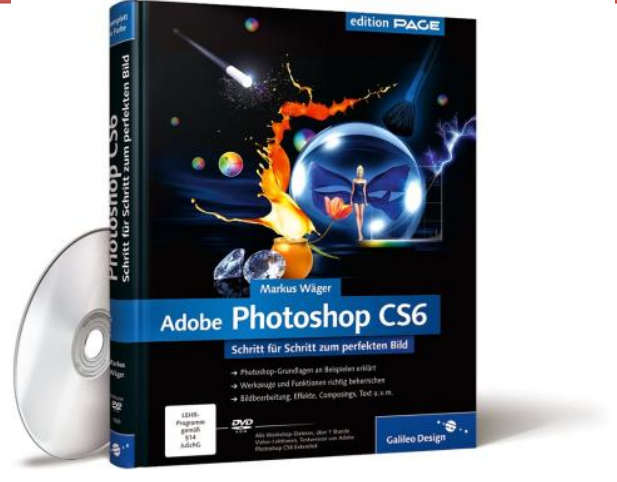

Gambar 4. Perangkat Lunak Adobe Flash CS6 (Sumber: programasjuegosgratisfull.blogspot.com)

Proses peneliti mengembangkan media flash (media pembelajaran Bahasa Indonesia) di awali berkonsultasi dan kerja sama dengan mantan mahasiswa Univer-sitas Muhammdiyah Jember, FKIP yang bernama Ijul Baidi, S.Pd. Proses ini bertujuan menyamakan konsep dan tujuan akhir yang diharapkan. Setalah dikembang-kan dan diuji coba dari berbagai pengguna dan kalangan ahli, peneliti mendapatkan saran, kritik dan masukkan yang berguna. Proses, uji coba ini berguna untuk menghasilkan produk dengan sedikit kekurangan atau mendekati sempurna.

Berdasarkan prosedur penelitian yang telah direncakan dan tahap uji coba mendapatkan hasil sebagai berikut.

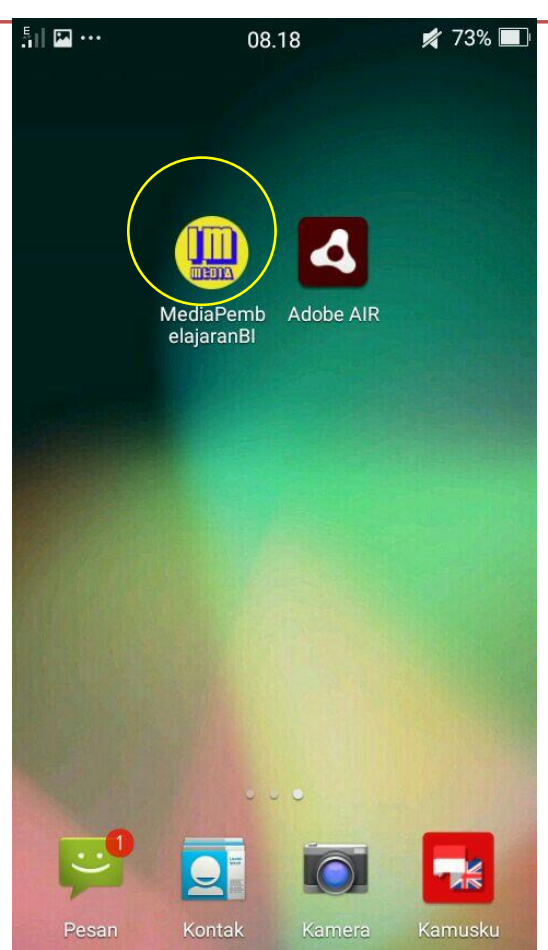

Gambar 5. Gambar media saat sudah di instal di HP Android

Gambar di atas (yang dilingkari) menunjukkan bahwa peneliti telah berhasil mengembangkan media pembelajaran (perkuliahan) dengan basis atau sistem android. Aplikasi tersebut diberi man "MediaPembelajaranBI". Perangkat lunak ini berisi konten- konten yang telah dise-suaikan dengan mata kuliah Bahasa Indonesia.

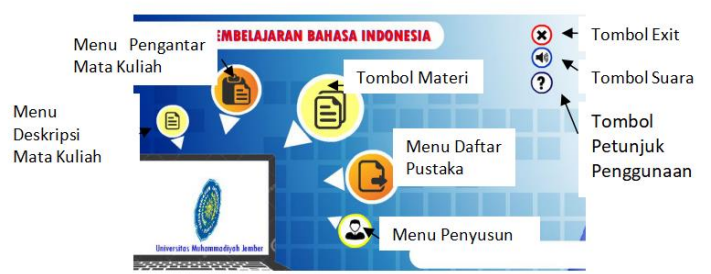

Gambar 6. Tampak dari Home di media yang dikembangkan

Berdasarkan hasil uji coba dari menu utama dari media berbassis flash ini berisi beraneka ragam tombol menu dan pengaturan lainnya. Gambar di atas terdapat tombol materi perkuliahan bahasa Indonesia, pengantar mata kuliah, deskripsi mata kuliah, daftar pustaka, dan profil penyusun. Selain itu 
Agus Milu Susetyo: Pengembangan Media Pembelajaran untuk Mata Kuliah Bahasa Indonesia Berbasis Android

Website : https://jurnal.umj.ac.id/index.php/penaliterasiEmail : penaliterasi@umj.ac.id

di pojok kanan atas terdapat 3 tombol yang fungsi berbeda-beda. Tombol paling atas (tanda silang) adalah tombol untuk meluar dari menu (exit), tombol dengan tanda speaker berfungsi membuka dan menutup suara pengiring ketika menggunakan media ini. Selain itu, terdapat tombol yang simbol "tanda tanya" yang fungsinya memberikan "petunjuk atau cara penggunaan" media flash kepada pengguna.

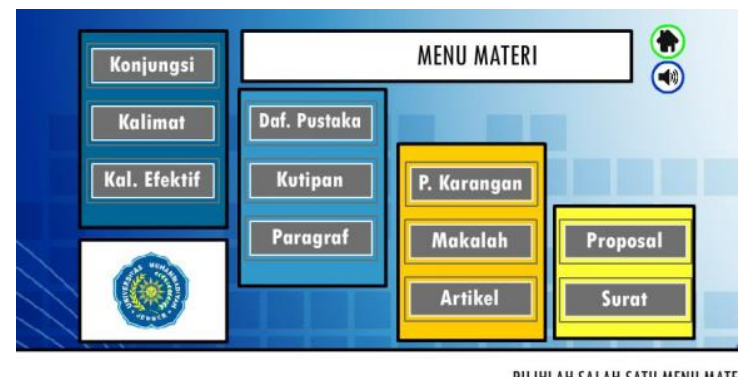

Gambar 7. Tampilan ragam materi dalam media yang dikembangkan

Gambar 7 (di atas) merupakan tampilan menu materi pada media flash yang dikembangkan peneliti. Menu ini berisi beberapa materi perkuliahan yang diper-lukan pada mata kuliah Bahasa Indonesia. Materi perkuliahan di menu ini diambil dari beberapa referensi yang dipilih peneliti sesuai dengan kompetensi yang diharapkan dari mata kuliah. Penyesuaian perlu dilakukan karena beberapa buku referensi dari buku bahasa Indonesia di perguruan tinggi namun tidak semua di masukkan.

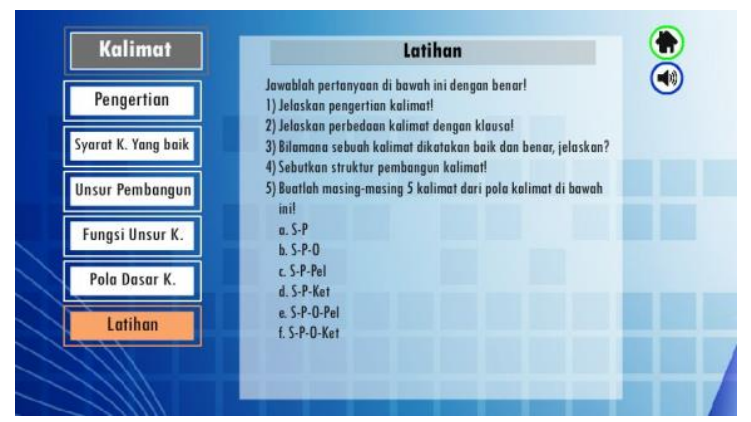

Gambar 8 Tampilan salah satu materi dari media (kalimat)
Gambar di atas merupakan beberapa contoh tampilan dari dalam menu materi dalam media yang dikembangkan peneliti. Materi yang terdapat dalam menu materi merupakan materi yang bersifat konsep dari mata kuliah Bahasa Indonesia. Selain itu, peneliti juga menambahkan menu "latihan" di masing-masing menu materi. Latihan yang dibuat disusun untuk memperdalam penguasaan dari pengetahuan pengguna (mahasiswa) setelah mempelajari konsep-nya.

Dalam menu latihan berisi soal-soal yang disesuaikan dengan konsep yang dipelajari mahasiswa. Bentuk dari soalnya adalah soal uraian. Setiap menu materi yang dipilih oleh penggunaan ditampilan di pojok kanan dua tombil yang berbeda. Pertama adalah tombol untuk kembali ke menu utama yang berbentuk rumah. Kedua adalah tombol untuk menghidupkan dan mematikan musik penggiring (backsound).

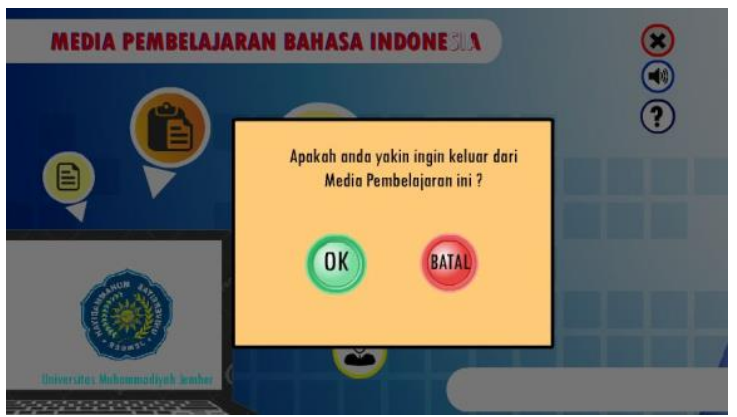

Gambar 9. Tampilan Ketika Ingin Keluar dari Aplikasi (Media)

Gambar di atas merupakan tampilan gambar ketika pengguna menekan tombol keluar (bertanda silang) yang berada di pojok kanan atas tepatnya diposisi paling atas. Setelah pengguna menekan tombol ini, akan keluar kotak pemberitahuan, apakah pengguna ingin benar-benar keluar dari aplikasi yang sedang berjalan atau tidak (membatalkannya). Jika pengguna ini keluar dari aplikasi yang berjalan tinggal menekan 
Agus Milu Susetyo: Pengembangan Media Pembelajaran untuk Mata Kuliah Bahasa Indonesia Berbasis Android

Website : https://jurnal.umj.ac.id/index.php/penaliterasiEmail : penaliterasi@umj.ac.id

"ok" dan untuk membatalkan dengan materi di dalam flash sudah disesuaikan menekan tombol "batal".

\section{KESIMPULAN}

Deneliti mengembangkan media berbasis
flash yang cocok untuk gawai ini khusus flash yang cocok untuk gawai ini khusus untuk mahasiswa. Mahasiswa yang dimaksud adalah mahasiswa yang menempuh matakuliah Bahasa Indonesia di lingkungan Universitas. Hal yang menja-di perhatikan peneliti adalah maraknya mahasiswa yang menggunakan smart-phone (gawai) yang berbasis Android. Hp mereka harus dimaksimalkan fungsinya, bukan hanya sebagai alat komunikasi, namu bisa dimanfaatkan sebagai media pembelajaran atau perkuliahan.

Media yang dikembangkan penelitia dibuat dengan menggunakan perangkat lunak berupa Adobe Flash CS. Alasan utama peneliti menggunakan perangkat lunak versi terbaru karena dapat mendukung untuk pengembangan aplikasi Android dan Ios. Berkat vitur ini dulunya produk flash yang hanya bisa diputar melalui komputer sekarang bisa dimasukkan ke dalam smartphone (gawai).

Berdasarkan hasil uji coba kepada mahasiswa dan membagikan angket kepada ahli materi dan media di lingkungan Universitas Muhammdiyah Jember mengahasilkan keputusan bahwa media yang dikembangkan bersifat implemenatatif. Artinya dapat digunakan untuk media pembelajaran kepada mahasiswa yang menempuh mata kuliah bahasa Indonesia. Hasil ini belum termasuk revisi. Beberapa kritik dan masukan setelah uji coba perlu diperhatikan oleh peneliti agar media atau produk yang dikembangkan semakin sempurna.

Berdasarkan hasil analisis dan uji coba didapat beberapa kegunaan. Pertama, dengan deskripsi mata kuliah Bahasa Indonesia, sehingga bisa dikatakan cocok tidak berlebihan atau kekurangan. Kedua, media flash ini memiliki ukuran byte yang kecil (sekitar $10 \mathrm{mb}$ ). Selain itu, mudah untuk digandakan atau disalin ke hp lainnya. (menggunakan bluetooth atau aplikasi Share It). Ketiga, dengan basis aplikasi Android dan mudah dipasang di hp, media ini mudah untuk dibawa kemana-mana layaknya mengantongi gawai pada umum-nya.

Sementara itu, ada beberapa catatan penting ketika menggunakan media ini. Pertama, media berbasis flash masih belum terdaftar pada Google Playstore sehingga menyeba-rannya atau pendistribusiannya masih mela-lui hp. Oleh karena itu, dosen pembimbing diharapkan mempunyai media ini terlebih dahulu dengan menyalin dari peneliti kemudian mendistribusikan ke mahasiswanya. Kedua, variasi soal pada setiap materi masing menggunakan jenis soal uraian dan mahasiswa mengerjakannya di tempat terpisah (lembar jawaban tersendiri) tidak terintegrasi dalam media flash. Ketiga, penggunan masih membutu-hkan aplikasi pendukung untuk menja-lankan media ini yaitu Adobe Air. Aplikasi ini sudah ada di Google Playstore, lalu di unduh dan dipasang. Jika sudah memasang Adobe Air, pengguna bisa membuka (memakai) media pembelajaran Bahasa Indonesia. Jika menginginkan aplikasi atau perangkatnya klik "disini". langkah selanjutnya adalah pengguna juga wajib untuk memasang aplikasi pendamping berupa Adobe Air. Aplikasi tersebut sebagai pelengkap, karena jika perangat medianya sudah terpasang tidak akan terbuka jika belum memasang Adobe Air. Klik "disini" untuk mengunduh. 
Agus Milu Susetyo: Pengembangan Media Pembelajaran untuk Mata Kuliah Bahasa Indonesia Berbasis Android

Website : https://jurnal.umj.ac.id/index.php/penaliterasiEmail : penaliterasi@umj.ac.id

\section{UCAPAN TERIMA KASIH}

$\mathrm{U}$ Capan terimakasih peneliti tujukan kapada Universitas Muhammadiyah Jember yang telah menjadi penyan-dang dana, khusunya LPPM. Selanjutnya, kepada ahli media, materi dan mahasiswa yang memberikan kontribusi untuk menyempurkan media yang telah dikembangkan. Terimakasih juga untuk Hijul Baidi yang telah menjadi rekan diskusi peneliti saat mengembangkan media ini.

\section{REFERENSI}

Arifin, Zaenal dan Amran Tasai. 1985. Berbahasa Indonesia untuk Perguruan Tinggi. Jakarta: Mediyatama sarana Perkasa.

Arsyad, Azhar. 2005. Media Pembelajaran. Jakarta: Grafindo Persada.

Artati, Budi. 2009. Baku dan Tidak Baku. Klaten: Intan Pariwara.

Asnawir dan M. Basyiruddin Usma. 2002. Media Pembelajaran . Jakarta: Ciputat Pers.

Chaer, Abdul. 2011. Ragam Bahasa Ilmiah. Jakarta: Rinneka Cipta.

Dalman. 2012. Menulis Karya Ilmiah. Jakarta: Raja Grafindo Persada.

Hendryadi. Content Validasi. (2014). [Online] Tersedia: (https://www.teorionline.net/contentva lidity. [1 Juni 2017]

Hikmat, Ade dan Nani Solihati. 2013. Bahasa Indonesia. Jakarta: Kompas Gramedia.

Keraf, Gorys. 1984. Tata Bahasa Indonesia: Sekolah Menengah Tingkat Atas. Jakarta: Nusa Indah.
K, Ichwan. 2016. Membuat Media Pembelajaran dengan Adobe Flash CS 6. Yogyakarta: Andi.

Komputer, Wahana. 2009. Teknik Pembuatan Animasi Dengan Adobe Flash CS 3. Jakarta: Salemba Infotek.

Nazar, A. Noerzihri. 2006. Bahasa Indonesia dalam Karangan Ilmiah. Bandung: Humaniora.

Moeleong, Lexy J. 2000. Metodologi Penelitian Kualitatif. Bandung: PT. Remaja Rosyda Karya.

Pusat Pembinaan dan Pengembangan Bahasa. 1993. Pedoman Umum Ejaan Bahasa Indonesia Yang Disempurnakan. Jakarta: Gramedia Widia Sarana Indonesia.

Rahmadi. 2011. Modul Pembuatan Media Pembelajaran Menggunakan Macromedia Flash. [Online]. Tersedia: (https://www.scribd.com/doc/7413227 5/Modul Pembuatan-MediaPembelajaran-Menggunakan-MacroMedia-Flash-8. [15 April 2017].

Sadiman, A.S. 1986. Media Pendidikan: Pengeratian, Pengembangan, dan Pemanfaatannya. Jakarta: Cv. Rajawali.

Sukmadinata, Nana Syaodih. 2013. Metode Penelitian Pendidikan. Bandung:. Remaja Rosdakarya.

Sora. 2016. Pengertian Proposaul Dan UnsurUnsurnya Serta Sistematikanya. From: http://www.pengertianku.net/2016/12/ pengertian-proposal-dan-unsurunsurnya-serta-sistematikanya.html, [Online]. Tersedia. [07, Nopember 2017].

Yunohudiyono, dkk. 2007. Bahasa Indonesia Keilmuan. Surabaya: UNESA University Press 